\title{
Serum immunoglobulins in acute anterior uveitis
}

\author{
RICHARD MCCOY, ' ? LAURINE WHITE, ' BRIAN TAIT, 3 AND \\ ROLAND EBRINGER ${ }^{\prime 2}$
}

From the 'Department of Medicine, University of Melbourne, Austin Hospital; the ${ }^{2}$ Uveitis Research Clinic, the Royal Victorian Eye and Ear Hospital; and the ${ }^{3}$ Tissue Typing Laboratory, Royal Melbourne Hospital

SUmmary Serum levels of immunoglobulin A, G, and $M$ were examined in 99 patients with acute anterior uveitis (AAU). The mean level of serum $\operatorname{IgA}$ was raised $(p<0.001)$ in AAU patients when compared with healthy control subjects. The levels of serum IgG and IgM were not significantly different from those in the control group. The raised levels of serum IgA were found to occur predominantly in the HLA-B27 positive group of patients $(\mathrm{p}<0 \cdot 001)$ and were highest in HLA-B27 positive patients with sacroiliitis or associated spondylarthritic diseases $(p<0 \cdot 001)$. The HLA-B27 negative group of AAU patients did not have a significantly raised mean serum IgA. The raised level of serum IgA in HLA-B27 positive AAU patients suggests that there has been a response to an environmental or infectious agent(s) acting across a mucosal tissue in these patients. This agent could be responsible for the initiation of the acute ocular inflammation.

The aetiology of acute anterior uveitis (AAU) is not known. It is probably a collection of heterogeneous conditions. Ankylosing spondylitis (AS) and other related forms of arthritis known collectively as the seronegative spondylarthropathies $(\mathrm{SpA})$ are known to be associated with AAU.' These associations became clearer following the discovery that over $90 \%$ of AS patients and a high proportion of patients with SpA carried the HLA tissue antigen B27. 'Subsequent studies showed that about $50 \%$ of all AAU patients possessed the B27 antigen, and that virtually all AAU patients with an associated arthritis were found in the B27 positive $(\mathrm{B} 27+)$ group. $^{3+}$

Other studies have shown that AS patients with active inflammatory disease had raised serum and salivary secretory $\operatorname{IgA}$, whereas AS patients with inactive disease had normal values. ${ }^{5}$ "It was suggested that these results reflected an immunological response to an infectious agent acting upon a mucosal surface in these patients.

A common aetiology and pathogenesis for the eye inflammation in HLA-B27 positive AAU and the spinal and peripheral joint inflammation of AS has been proposed. ${ }^{7}$ It was therefore decided to examine serum immunoglobulin levels in AAU patients and to determine if there were differences between the HLA B27+ and B27- subgroups.

Correspondence to $\operatorname{Dr} \mathrm{R}$. Ebringer, Department of Medicine, University of Melbourne, Austin Hospital, Heidelherg. VIC 3084. Australia.

\section{Patients and methods}

A uveitis research clinic has been established at the Royal Victorian Eye and Ear Hospital. The first 100 consecutive patients presenting within four weeks of an onset of an acute first attack or a recurrence of AAU were included in the study. Patients with chronic uveitis (that is, requiring more than three months' treatment) or with posterior uveitis were excluded. The mean age of the patients was 41.5 years with a range of 13 to 78 years, and 54 were male. Sixtysix healthy non-hospital subjects recruited from general practitioner lists and university staff provided the control group. The mean age of the control subjects was $36 \cdot 3$ years with a range of 16 to 78 years, and 34 were males. Each patient and control subject was examined, a history obtained, and blood drawn for examination. Where indicated pelvic or spinal radiographs were taken. Tissue typing was performed by the standard microlymphocytotoxicity tests. Serum immunoglobulins were measured by radial immunodiffusion using commercially available plates (Calbiochem-Behring). Statistical analyses were performed by Student's $t$ test.

\section{Results}

One patient was excluded as his blood sample was subsequently discovered to have been taken six weeks after the onset of his ocular symptoms. Of the remain- 
Table 1 Serum immunoglobulins in patients with acute anterior uveitis in $\mathrm{mg} / \mathrm{l}$

\begin{tabular}{|c|c|c|c|c|}
\hline & & $I g A \pm(S E M)$ & $I g G \pm(S E M)$ & $\operatorname{IgM}(S E M)$ \\
\hline \multirow[t]{4}{*}{ Patients } & $\begin{array}{l}\text { HLA-B27-SpA- } \\
n=46\end{array}$ & $231 \cdot 5 \pm 16 \cdot 6$ & $1137 \pm 52$ & $135 \cdot 6 \pm 8 \cdot 3$ \\
\hline & $\begin{array}{l}\text { HLA }-B 27-S p A+ \\
n=5\end{array}$ & $292 \cdot 2 \pm 89 \cdot 2$ & $918 \pm 81$ & $139 \cdot 4 \pm 22 \cdot 0$ \\
\hline & $\begin{array}{l}\mathrm{HLA}-\mathrm{B} 27+\mathrm{SpA}- \\
\mathrm{n}=23\end{array}$ & $257 \cdot 8 \pm 15 \cdot 8$ & $1114 \pm 72$ & $140 \cdot 6 \pm 13 \cdot 8$ \\
\hline & $\begin{array}{l}\text { HLA-B27+ SpA }+ \\
n=25\end{array}$ & $296 \cdot 8 \pm 22 \cdot 3$ & $1284 \pm 63$ & $156 \cdot 3 \pm 17 \cdot 8$ \\
\hline Controls & $n=66$ & $195 \cdot 4 \pm 11.05$ & $1219 \pm 40$ & $149 \cdot 8 \pm 8 \cdot 1$ \\
\hline
\end{tabular}

ing 99 patients $48(48 \%)$ were found to be $\mathrm{B} 27+$. Thirty patients were found to have an associated rheumatic disease. Of those 25 were B27+ and either had AS or typical back pain symptoms plus radiological sacroiliitis. There were five patients who were B27- with associated rheumatic diseases. One of these patients had Behçet's disease and carried the appropriate tissue marker HLA-B5.1. Two other patients had psoriasis and peripheral arthritis. None of these three had sacroiliitis. Because of the heterogeneous rheumatic conditions and the small numbers of patients in this group their results were excluded from the main statistical analysis and analysed separately. The results of the mean serum immunoglobulin and standard errors of the mean of the various patient and control groups are shown in Table 1.

There was no clinical evidence to suggest that

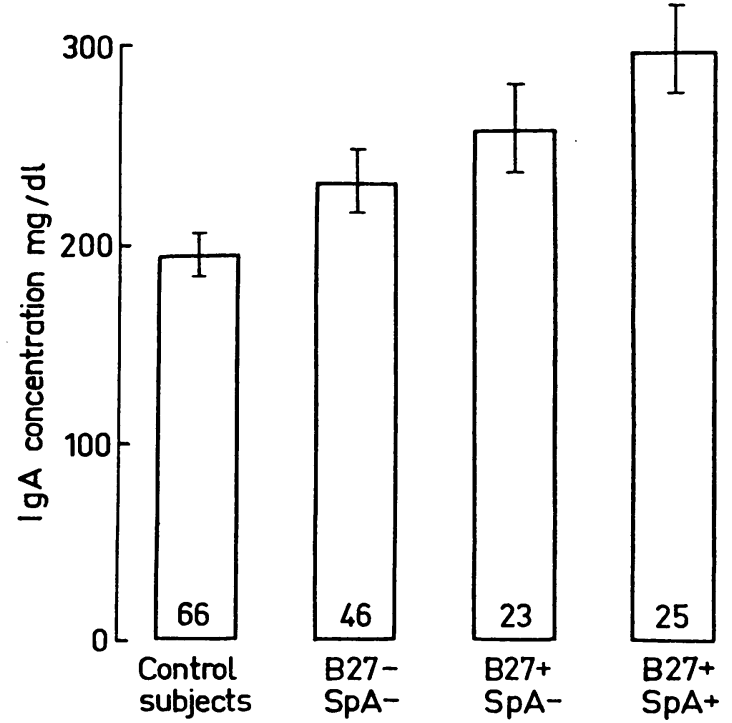

Fig. 1 Mean serum IgA $\pm S E M$ in control subjects, and in three groups of $A A U$ patients: $B 27-S p A-, B 27+S p A-$, $B 27+, \mathrm{SpA}+$. patients with $\mathrm{SpA}$ had an exacerbation of arthritis during their episode of AAU.

Serum $\operatorname{Ig} A$. The mean serum $\operatorname{IgA}$ and standard errors of the mean in each patient group are shown in Fig. 1. There was a significant increase in mean serum $\operatorname{IgA}$ in all the AAU patient groups combined when compared with controls $(t=3 \cdot 83, \mathrm{p}<0 \cdot 001)$. This elevation was predominantly due to the HLA-B27+ patient groups $(t=4 \cdot 29, \mathrm{p}<0.001)$ and particularly to the B27+ patients with $\operatorname{SpA}(t=4 \cdot 08, \mathrm{p}<0 \cdot 001)$. There was no significant difference in mean $\operatorname{IgA}$ between controls and the B27- patient group $(t=$ $1 \cdot 81, \mathrm{NS})$. There was a significant difference in mean serum IgA when the B27+ group was compared with the B27- group $(t=2 \cdot 04, \mathrm{p}<0.05)$. There was no significant difference in IgA between the B27+ SpA + and $\mathrm{B} 27+\operatorname{SpA}-\operatorname{groups}(t=1 \cdot 24, \mathrm{NS})$.

Serum $\lg G$. The results for mean levels of serum IgG are shown in Fig. 2. There were no significant

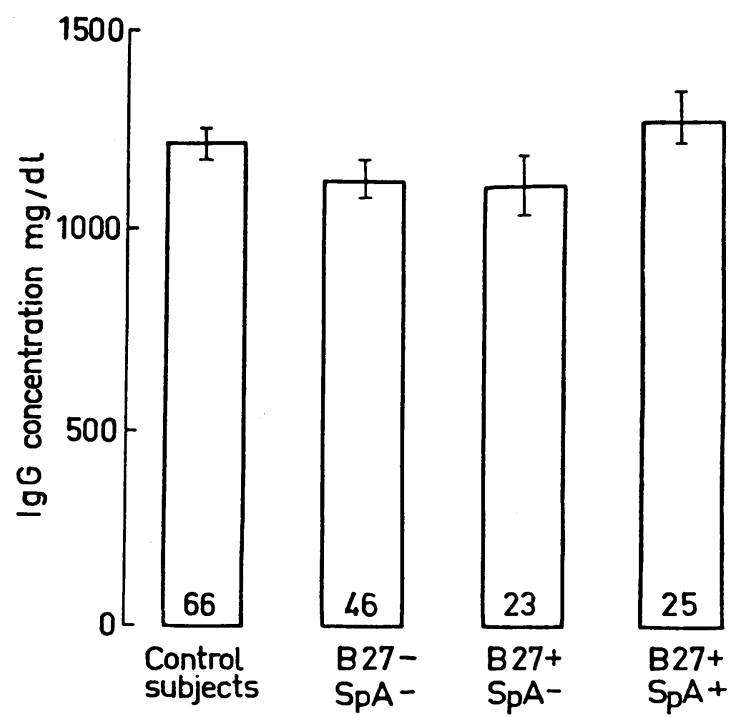

Fig. 2 Mean serum IgG $\pm S E M$ in control subjects and in three groups of $A A U$ patients: $B 27-S p A-, B 27+S p A-$, $B 27+, \mathrm{SpA}+$. 


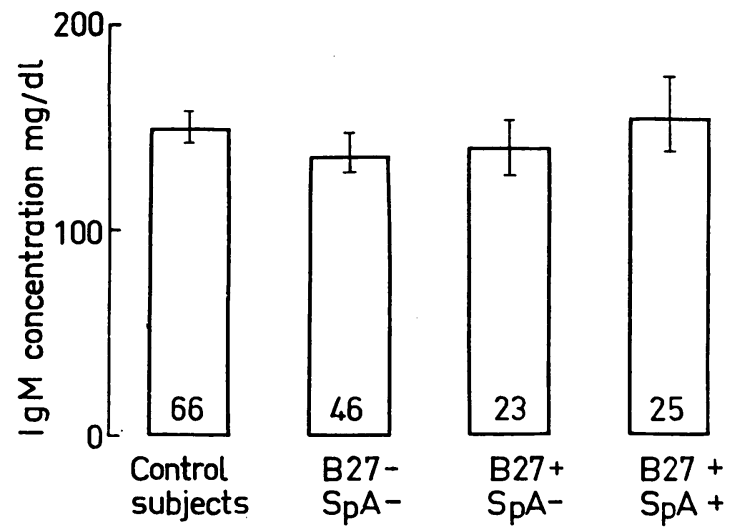

Fig. 3 Mean serum IgM $\pm S E M$ in control subjects and in three groups of $A A U$ patients: $B 27-S p A-, B 27+S p A-$, $B 27+, \mathrm{SpA}+$.

differences in any of the patient groups studied when compared with control subjects. However, patients who were B27 - SpA - had a significantly lower mean serum IgG than the B27+SpA+ patient group $(t=$ $2 \cdot 04, \mathrm{p}<0 \cdot 05)$.

Serum IgM. The results for serum IgM are shown in Fig. 3. There were no significant differences between the serum IgM values of any of the AAU patient subgroups and control subjects or between patient subgroups.

\section{Discussion}

The results show that in our series just under $50 \%$ of patients with AAU carry the B27 antigen. Thirty out of 99 patients were found to have an associated SpA. Of these patients 25 had the HLA B27+ antigen. These results are in close agreement with previous studies. $^{34}$ It is clear that most AAU patients who have an associated rheumatic disease carry the HLA-B27 antigen.

The results show a striking increase of mean serum IgA in B27+ AAU patients and particularly the B27+ SpA+ patients. The levels obtained were similar to those found in AS patients with clinically and biochemically active inflammatory disease and were higher than the levels found in AS patients with inactive inflammatory disease. ${ }^{\circ}$

The critical factor segregating the AAU patient groups into a high or a normal level of $\operatorname{IgA}$ appeared to be the presence of HLA-B27. The B27- patients as a group did not have a significantly raised IgA above controls, whereas the $\mathrm{B} 27+$ patients did. In addition, the serum $\operatorname{IgA}$ in B27+ patients with and without arthritis was not significantly different.

Statistical analysis of the immunoglobulin in the five B27- SpA+ patients was not carried out, as there was only a small number of values and a very wide scatter of results obtained.

It is of note that in all cases examined patients with an associated SpA did not have a clinically significant exacerbation of arthritis or sacroiliac symptoms during the episode of AAU. It is presumed that the raised serum IgA was related to the episode of AAU. However, low grade asymptomatic spinal inflammation (as demonstrated by increased radioisotope uptake) in the sacroiliac joints during AAU has been reported. ${ }^{x}$ This question of low grade extraocular inflammation occuring during attacks of AAU needs to be assessed by further studies.

Previous investigations on immunoglobulin levels in AAU have been conflicting. Norn reported an increase in serum IgA and IgG but not IgM in patients with AAU." These results were in marked contrast to those of Rahi $e t$ al., who noted a rise of serum IgM but not IgG or IgA."' It should be noted that both of these studies were carried out prior to the availability of HLA tissue typing. Our findings are more in favour of those reported by Norn, but we did not demonstrate a raised serum IgG. If anything our studies suggest a mild decrease in serum IgG in the HLA-B27 - patient group.

We have previously demonstrated that patients with active inflammatory disease in AS (nearly all of whom are $\mathrm{B} 27+$ ) had a raised serum IgA." Comparable results have been obtained by other investigators who also reported a rise in salivary secretory IgA. ${ }^{6}$ Plasma cells in the mucosal associated lymphoid tissue (MALT) are the major source of IgA. "Investigations in animals raised in germ-free conditions have shown that after oral immunisation the main specific plasma cell response is $\operatorname{IgA}$ in character, and nearly all the circulating specific antibody is $\operatorname{IgA} .^{12}$ It has been postulated that the findings of a raised serum IgA in active AS suggested that an infectious agent (probably acting across the gastrointestinal tract) is stimulating the production of serum IgA and that this micro-organism may also be responsible for the active inflammation. The finding of a raised serum $\operatorname{IgA}$ in B27+ AAU patients (but not in B27- patients) suggests that a similar process occurs during $A A U$ in B27+ patients. Data in preparation suggests that a specific gram negative enteric micro-organism may be recovered from the faeces of a significant proportion of cases of AAU.

Examination of follow-up sera after the ocular inflammation has settled may indicate whether raised serum IgA values in AAU return to the normal range. This may provide further evidence of a direct temporal relationship between episodes of AAU and raised serum $\operatorname{IgA}$. Recent studies have reported that patients with AS had raised levels of IgA antibody to klebsiella micro-organisms..$^{13}$ It may be useful to 
search for a specific antibody to Gram-negative intestinal bacteria in AAU.

Investigations during epidemics of dysentery have shown that infection with Gram-negative enteric pathogens such as shigella, ${ }^{14}$ salmonella, ${ }^{15}$ or Yersinia enterocolitica ${ }^{16}$ are capable of initiating or triggering episodes of AAU. The individuals susceptible to this postdiarrhoeal AAU were frequently found to carry the HLA-B27 antigen and often developed other extraintestinal features such as arthritis at the same time. We have reported that Klebsiella pneumoniae, another Gram-negative micro-organism, is found more frequently in the faeces of AAU patients during acute exacerbations of inflammation of $\mathrm{AS}^{17}$ and during episodes of AAU in AS. ${ }^{1 \times}$ These results have been confirmed by others. ${ }^{19-21}$

Our results showing a raised serum IgA in $\mathrm{B} 27+$ AAU patients suggest that a search for Gramnegative intestinal bacteria and raised Gram-negative bacterial antibody levels in AAU would be of value.

We are grateful to the many ophthalmologists, particularly Dr B. Coote, who referred patients to us for investigation. We are also grateful to Janet Finlayson who typed the manuscript.

These studies were supported by a grant from the OPSM Foundation, the Austin Hospital Research Foundation, and a research project grant from the Royal Victorian Eye and Ear Hospital.

\section{References}

I Stanworth A, Sharp J. Uveitis and rheumatic diseasc. Ann Rheum Dis 1956; 15: 140-50.

2 Brewerton DA. HLA-B27 and the inheritance of susceptibility to rhcumatic disease. Arthritis Rheum 1976; 19: 656-68.

3 Brewerton DA. HL-A27 and acute anterior uveitis. Ann Rheum Dis 1976; 34 (suppl 1): 33-35.

4 Mapstone R. Woodrow JC. HL-A27 and acute anterior uveitis. BrJ Ophthalmol 1976; 59: 270-5.

5 Cowling P. Ebringer R. Ebringer A. Association of inflammation with raised scrum $\lg \mathrm{A}$ in ankylosing spondylitis. Ann Rheum Dis 1980: 39: 545-9.
6 Calguneri M, Swinburne L, Shincbaum R. Cook EM. Wright V. Secretory $\lg \mathrm{A}$; immune defence pattern in ankylosing spondylitis and klebsiclla. Ann Rheum Dis 1981: 40: 6(0)-4.

7 Ebringer RW. Editorial review HLA-B27 and the link with rheumatic diseases: recent developments. Clin Sci 1980; 59: 405-10.

8 Russel AS, Lentle BC, Percy JS, Jackson FI. Scintigraphy of sacroiliac joints in acutc anterior uveitis. Ann Intern Med 1976; 85: 6)6-8.

9 Norn MS. Immunoglobulins in endogenous uveitis. $\mathrm{Br} \mathrm{J} \mathrm{Oph-}$ thalmol 1976; 60: 299-301.

10) Rahi AHS, Holborow EJ, Perkins ES, Gungin YY, Dinning WJ Immunological investigations in uveitis. Trans Ophthalmol Soc UK 1976: 96: 113-22.

11 Lamm ME. Cellular aspects of immunoglobulin A. Adv Immunol 1976; 22: 223-90.

12 Crabbe PA, Nash DR, Bazin M, Eyssen H, Heremans JF. Antibodies of the $\lg A$ type in intestinal plasma cells of germ free mice after oral or parenteral immunization with ferritin. $J$ Exp Med 1969; 130: $723-44$.

13 Trull A, Ebringer R. Panayi GS. Colthorpe D. James DCO, Ebringer A. IgA antibodies to Klcbsiclla pncumoniac in ankylosing spondylitis. Scand J Rheumatol in press

14 Paronen I. Reiter's disease, a study of 344 cases observed in Finland. Acta Med Scand 1948; 131 (suppl 1213): 1-114.

15 Saari KM, Vilpula A. Lassus A, Leirisalo M. Saari R. Ocular inflammation in Reiter's discase after salmonella enteritis. Am J Ophthalmol 1980; 90: 63-8.

16 Mattila L, Granfors K. Toivanen A. Acute anterior uveitis after yersinia infection. BrJ Ophthalmol 1982; 66: 209-12.

17 Ebringer RW, Cawdell D, Cowling P, Ebringer A. Sequential studies in ankylosing spondylitis: Association of klcbsiclla pneumoniac with active discase. Ann Rheum Dis 1978; 37: 14651.

18 Ebringer R, Cawdell D. Ebringer A. Klebsiella pneumoniae and acutc anterior uveitis in ankylosing spondylitis. $B r$ Med J 1979; i: 383.

19 Eastmond CJ, Calguneri M. Shincbaum R, Cooke EM, Wright V. A sequential study of the relationship between faccal Klebsiella aerogenes and the common clinical manifestations of ankylosing spondylitis. Ann Rheum Dis 1982; 41: 15-20.

20) Willshaw HE, Eastmond CJ. Role of environmental factors in uveitis. Trans Ophthalmol Soc UK 1979: 99: 16()-2.

21 Kuberski TT, Morse HG, Rate RG, Bonnell MD. Increased recovery of klebsiella from the gastrointestinal tract of Reiter's syndrome and ankylosing spondylitis patients. Arthritis Rheum $1981 ; 24$ (suppl 1): 78. 